\title{
Labour market discrimination and employment in South Africa
}

\author{
B. Urban Lombard \\ The Premier Group Limited, Johannesburg
}

The purpose of this paper is to critically analyse the occupational structure determinants for the different race/sex groups within the manufacturing sector of South Africa. This study is carried out in the theoretical framework of the human capital school and dual labour market theory approaches.

This research derived its importance from the phenomena of high unemployment. low occupational status, and the underutilization of Blacks in the labour market. The aim of this study is to focus on the Blacks' human capital invest. ment, their underutilization and employment problems. The results obtained highlight the development and employment opportunities for Blacks and provide guidelines to individuals and employers on how to combat labour market discrimination.

S. Afr. J. Bus. Mgmt. 1981, 12: 64-69

Die doel van hierdie artikel is om die beroepstruktuurdeterminante volgens ras- en geslagsgroepe in die vervaardiging. sektor van Suid-Afrika krities te ontleed. Die studie is gebaseer op die teoretiese raamwerk van die menslike kapitaalskool en die dualistiese arbeidsmarkbenaderings.

As gevolg van die groot tekort aan geskoolde mannekrag het die studie sy belangrikheid verkry in die verskynsels van hoë werkloosheid, lae beroepstatus en die onderbenutting van nie-Blankes in die arbeidsmark. Die oogmerk met hierdie studie is om op die nie-Blanke se menslike kapitaalinvestering, onderbenutting en indiensnemingsprobleme te fokus.

Die resultate het tot verskeie gevolgtrekkings gelei wat die menslike hulpbronontwikkeling en -bestuur in Suid-Afrika onderstreep het. Hierdie gevolgtrekkings en aanbevelings beklemtoon en hou verband met die ontwikkeling en indiens. nemingsgeleenthede vir nie-Blankes en sommige van die gevolgtrekkings bied riglyne vir individue en werkgewers oor hoe om arbeidsmarkdiskriminasie teen te werk.

S.-Afr. Tydskr. Bedryfsl. 1981, 12: 64-69
Labour market discrimination is considered to be one of the most eroding and powerful forces affecting the employment and development of human resources. To the employer it poses the problem of labour supply and to the individual, it produces low incomes, educational inequality and limits the utilization of his skills.

The purpose of presenting the measure of occupational index is to test the hypothesis that the elimination of overt employment discrimination will make little change in the occupational position of the race/sex groups unless the penetration patterns and distribution of these occupational determinants are radically changed.

This investigation also proposes to further the understanding of the manpower policy implications, particularly as it relates to the employer, by analyzing several of the occupational structures and variables directly and indirectly related to occupational positions within a subindustry of manufacturing. It is expected that the impact of these employment determinants on the employer, industry, state, as well as the worker, will be of cardinal importance to the future employment and manpower development policies in South Africa.

\section{Human resources management approach}

Human resources management is viewed as being a systematic effort by the employer to insure an effective and efficient interface between the enterprise's labour resource and its external environment. An effective interface is considered to be one where the organization pursues the most favourable ratio between its input (resources) and output (objectives) factors, given the constraints imposed by each one upon the other. A necessary though not sufficient condition of an effective and efficient system is state policies which do not discourage or prevent the economical allocation and utilization of the factors of production. One of the more fundamental attributes which distinguish a systems approach in human resource management to the traditional industrial psychological view of personnel administration is that it considers human resources costs to be an investment rather than an unaccountable expense. ${ }^{1, p .16}$

This principle would generally be acceptable to managers throughout South Africa. On average most employers have not consciously discriminated against their employees. The overt discrimination on the part of employers has been the direct result of the government's 
discriminatory labour, industrial relations and manpower utilization policies which have restricted the development and use of the non-White labour force. As a result of these prolonged inhibiting discriminatory policies, a serious shortage of skilled labour developed over the years. Owing to internal and external economic and political pressures, employers in the Republic have become positively interested in and committed to removal of discrimination in their employment practices and personnel policies. They have signified this commitment through becoming signatories to the South African Consultative Committee on Labour Affairs (SACCOLA) and the Urban Foundation's Code of Employment Practice. The SACCOLA code is endorsed by employers of roughly $85 \%$ to $90 \%$ of all employees in South Africa and with this action employers have committed themselves to eliminate the entrenched employment practices that discriminate particularly against Blacks.

The application of sound human resources development and management policies is therefore highlighted when one compares the 1978 ratio of White to Black and other economically active persons in the U.S.A. and South Africa. The U.S.A. has an 8:1 ratio in favour of , Whites, whereas South Africa is faced with a reversed 1:5 ratio in favour of Blacks. This paper will therefore attempt to shed more light on the causes of the high unemployment rates and low occupational status among the non-White groups (Asians, Blacks and Coloureds) in South Africa.

To understand the dynamics and forces underlying the determinants for low employment status and income among non-Whites, the human capital school begun by Schultz ${ }^{2}$ and the dual labour market theory usually attributed to Doeringer and Piore ${ }^{3}$ was used.

In the light of South Africa's peculiar labour market (very distinctly segmented along race and geographical lines with a dual economic structure in urban and rural areas), and the premises underlying the above schools of thought, the writer believes that the South African government has grossly neglected to recognize the economic costs of its restrictive manpower policies and has imposed a burden on the entire nation by its failure to develop its human resources to its full potential over the last two decades. This has, in turn, caused employers to implement personnel policies and practice employment procedures that discriminated against non-Whites, raising production costs, impeding industrial progress and, being psychologically as well as economically damaging to Whites and non-Whites alike.

The researcher recognizes that one of the first and foremost economic development problems facing South Africa is the lack of well qualified skilled workers to handle the present economic needs of the country. This calls for the implementation of human resources development policies at the national level and the recognition that the most valuable asset a country can possess is its human resources.

\section{Statement of the problem}

The primary human resources management problem faced in South Africa falls into two dimensions. The first of these is the overutilization of some skills, knowledge and talent of individuals in the labour force and secondly, the apparent unwillingness by employers to develop and use Blacks. The logical consequence of this act is the underdevelopment and underutilization of the Black employee's potential, skills and capabilities.

Harbison ${ }^{4}$ believed that these two dimensions are interrelated and therefore mutually dependent, because '. . . underdevelopment of human resources is to some extent a cause of underutilization and vice versa'.

The South African occupational structure problem is further highlighted by the fact that:

- Whites represented only $18,8 \%$ of the Republic's total economic population in 1970, while being dominant in the white-collar occupations. The Coloureds and Asians totalled 11,1\%. Together with the Whites they represented around $30 \%$ of the total economic population, with the Blacks accounting for most of the $70 \%$ of the blue-collar jobs.

- With a decline in Black labourers and a slow-growing White professional and manager group, it is evident that South Africa is not experiencing a labour shortage but a severe shortage of skills.

From the aforegoing problem statement, it is true that:

- A great deal of time has already been lost, and we should not waste any of what is left to assure every individual who is willing to work the right to earn a living. At the moment there are too many individuals, particularly Blacks, for whom this right is not real, and if the South African system of free enterprise cannot or will not find ways to help them, they may well decide that the system is not worth having. 5. p.67

\section{Aim, purpose and objective of study}

The primary aim of this study is to put together what we know about the human capital of non-Whites and the manufacturing sector's occupational determinants that are necessary to produce appropriate policies and job upgrading programs for attacking the underdevelopment and underutilization problems.

The purpose of the analysis is to determine the extent and magnitude to which the differences in the occupational market and labour force characteristics that lie beyond the direct control or influence of employers, can account for the variance in occupation position by race and sex in the manufacturing sector. The unexplained variance will be considered to be the produce of a mixture of unspecified forces, one of which can be identified as institutional labour market discrimination.

The overall objective of this research is to identify, statistically, rather than normatively the major forces and determinants responsible for the relatively low occupational status and underutilization of the race/sex groups. The extent to which these variables are predictive indicators of occupational positions will be determined by a multi-variate regression model.

To give the clearest possible portrayal of the study's overall objective, this investigation is, furthermore, based on the notion that there is a set of factors over which employers exercise little control or influence, but which largely explain their relative occupational positions. This idea does not, however, imply that employers have no 
direct control over the magnitude of the variables, or that they have no influence on the structural parameters attached to the indicators. In fact, they do. For example, years of schooling for non-Whites or Whites are not determined by employers, but the development and utilization of each group's acquired human capital, relative to their respective occupational positions, are in turn determined by the employer's personnel policies and employment preferences.

To date, the human resources development experience in South Africa leaves a number of issues unresolved which are vital to any country's progress. One of the strategic questions this study sought to answer is:

What are the basic barriers blocking access to jobs for the Blacks? Are these barriers inherent in the characteristics of the people themselves, or are the employment determinants (barriers) inherent in the institutions of the society and the labour market and therefore requiring institutional change?

\section{Model criteria}

To find answers in varying degrees of depth to these questions, the following criteria are used in the selection of variables to explain the relative occupational distributions of race groups:

Variables are identified which are generally recognized as determinants of occupational position, or are closely associated with occupational penetration or position, e.g. age, education, income, sex, marital status and status of employment.

- Variables are selected which are relatively independent of the influence of other direct factors (as above) and are therefore identified as external to the occupational position system. These variables are proxies for economic and labour market conditions and are indicators of: economic growth, skill level demands, industry growth rates, geographical employment distribution, home language, job locations and housing, transportation systems and job market information.

- Variables in this category are considered to be the product of all those unspecified forces, influences and factors that have an impact on the variance not explained by the model, e.g. overt and covert employer discrimination practices, cultural bound value differences, or state policies.

The researcher has refrained from identifying de facto discriminating practices and attitudes, because of the difficulty in desegregating these influences on the other set of variables. Rayack's research supports this decision to the extent that: ' . . employers may continue to have the same subjective attitude toward discrimination yet be unable or unwilling to act accordingly because of extreme shortages in the labour market which make it difficult to hold or attract workers. Under such conditions the employer may suppress his subjective desires in favour of maintaining a stable labour force' ${ }^{6}$

\section{Methodology}

It is generally accepted that job upgrading is an ongoing process in the U.S.A. industry, and that many employees in primary jobs have moved up from lower levels. Similarly, many workers do not have a chance to advance. In South Africa, occupational inertia will not be a serious problem if it is confined to those in the upper three occupational levels, i.e. professional, managerial and sales workers. But this is not the case. Unfortunately, the Republic has no national longitudinal surveys that can shed light on how long some workers remain in their positions throughout their working life. According to this study's Index of Occupational Representation (IOP) calculations, it indicates that the majority of Blacks have remained in the lowest occupations and are overrepresented in the production and labourer occupations, whereas the Whites are the dominant group in the top three occupational levels, foreman and artisan positions. It is particularly the foreman and artisan positions where the highest labour supply shortages are currently being experienced.

In their comprehensive study Blau and Duncan, ${ }^{7}$ concluded that race was an independent factor affecting the prospects of worker mobility. They identified, in order, the major barriers to job advancement for U.S.A. Negroes as race, education and training, because Negroes, over the years, have been prevented from participating in the process of upward occupational mobility on an equal basis with Whites. In another study, Berg ${ }^{8}$ also found education to be significantly correlated to occupational status and income.

In this regard, the fundamental question is raised: To what extent and how well will South African non-Whites fare if they are given equal education, employment opportunities and social recognition as Whites? Will their chances of occupational advancement and career development remain considerably inferior to those of Whites?

\section{Research design and data base}

To seek an answer to this fundamental question, the investigation is designed as an ex post facto research study with the objective to analyse the occupational structure determinants and alternative labour policy implications in South Africa. The central hypothesis the study is investigating is whether the existing occupational structure, as measured by an index of occupational position, can significantly explain the race/sex occupational status by such objective factors as age, education, income, language, employment status, geographical area, and industry growth.

The data for this study are drawn from the National Population Census of 1970 which included all the race/sex groups in the manufacturing sector operating in the four main metropolitical regions, i.e. Pretoria-Witwatersrand-Vereeniging, Durban-Pinetown, Port Elizabeth-Uitenhage and Cape Town-Peninsula.

Access to data relating to persons was obtained through the Human Sciences Research Council's census tapes. The data consists of a 1:10 (10\%) sample of Whites, Coloureds, Asians and 1:5 (20\%) sample of Blacks for the 1970 census. The random sample sizes of the race/sex groups used in this study are: White males 8,624, White females 4,803; Coloured males 7,179, Coloured females 5,812; Asian males 4,332, Asian females 1,250; Black males 6,984 , Black females 2,212 . Totaling 
$41,196$.

This sample represents roughly $5 \%$ of the total manufacturing labour force in South Africa. The random sampling frame and statistical method applied is executed with the BMDO2R program. To test the main hypothesis a multiple stepwise regression model is applied separately to the eight race/sex groups. Firstly, from eight separate linear functions the between race/sex group occupational structure variance is estimated through the use of dummy variables. Secondly, the explanatory power of the independent variables is used to determine how much of the between race and sex group variance is explained by the independent variables included in the model. The regression analysis is also used to explain industry penetration rates (Black's share of employment) and occupational distribution by race and sex. If the residual is large, an explanation will be sought in the dual labour market theory that advocates that 'entry discrimination' is the primary form of labour market discrimination.

\section{Discussion of results}

The most significant correlations are found only among the relationships of Whites between education and income, i.e. 0,54 and 0,45 respectively. The remaining coefficients for all groups less than 0,144 is considered insignificant at the 0,05 level.

The summary results of the stepwise regression analysis for the 17 variables entered, with a minimum acceptable $F$ to enter of 0,01 and $F$ level for deletion of 0,005 , appear in Table 1.

From Table 1, the $\mathbf{R}^{2}$ for White males accounted for $41 \%$ of the variance in occupational position, whereas the $\mathrm{R}^{2}$ for White females explained $24 \%$; Coloured males $20 \%$, females $18 \%$; Asian males $28 \%$, females $19 \%$; Black males $7 \%$ and females $15 \%$.

The very small increases recorded in the $\mathbf{R}^{2}$ could be explained by the large sample sizes spread widely across 19 sub-manufacturing industries in four large metropolitan areas, all attempting to explain only fractional changes of one to two percentage points. It appears that the educational value for Whites is the strongest predictor for their occupational position. This was expected. The strongest predictors for occupational positions among the Coloureds and Asians are income, the paper industry and education. This was partially expected. Among the
Blacks, the unexpected appear. For Black males, the Cape Peninsula region accounted for the most variance and for their equation as a whole it only explained $7 \%$ variance. Industry growth surprisingly entered first for Black females explaining 3,7\%. In both cases of Blacks, regions and industries are stronger predictors than among the other groups where the cardinal variables (income and education) appear to be stronger. In the case of Blacks this was not expected and therefore it introduces in South Africa a somewhat contrary finding than to those studies of Parnes and Kohen'; Adams ${ }^{10}$; and Leigh".

The first two variables (education and income) as might be expected, are those obviously collinear with the occupational position of Whites. As years of schooling and income increase, so does their occupational level.

From the analysis of variance, the null hypothesis is rejected in all cases. One may thus perceive that occupational level is not, as predicted, purely associated with income, education and age of each of the race/sex groups, but is associated differently between them.

The unexplained variance in this study refers to an array of potentially interacting labour market forces that may individually or collectively interact with each other e.g. cultural or ethnic race differences, industry or union concentration, minimum wage legislation, labour market segmentation, restricted mobility of workers by legislation, extent of and access to job market information, family background and social environment work values and the like. Collectively one may interpret them as labour market discrimination acts which may, or may not be covert in nature.

By substituting the coefficient values of the White male's independent variables, the extent of the labour market occupational discrimination is determined. Of all the groups, Asian females are by far $(30,4 \%)$ the group most favourably discriminated in the labour market, followed by Asian males $(6,88 \%)$ and White females $(6,07 \%)$. The group experiencing the most severe labour market discrimination is Black females $(36,84 \%)$ followed by Coloured males $(5,42 \%)$.*

*See Lombard ${ }^{12}$ for technical details.

Table 1 Variables, multiple R's and increase in R squares for race/sex groups

\begin{tabular}{|c|c|c|c|c|c|c|c|c|c|}
\hline \multirow[b]{2}{*}{ Race/Sex } & \multirow[b]{2}{*}{$\begin{array}{c}\text { Total } \\
\mathbf{R}^{2}\end{array}$} & \multicolumn{8}{|c|}{ Variables entered and $R$ squares } \\
\hline & & Education & Income & English & Paper & Food & $\begin{array}{l}\text { Industry } \\
\text { growth }\end{array}$ & Durban & Cape \\
\hline Asian males & 0,28 & 0,1841 & 0,1207 & & 0,2295 & & & & \\
\hline Asian females & 0,19 & 0,1637 & 0,1292 & & & 0,1756 & & & \\
\hline Black males & 0,07 & 0,0321 & & & 0,0449 & & & & 0,0168 \\
\hline Black females & 0,15 & & & & & & 0,0371 & 0,0727 & 0,1035 \\
\hline Coloured males & 0,20 & 0,1417 & 0,1660 & & 0,0851 & & & & \\
\hline Coloured females & 0,18 & 0,1542 & 0,0882 & & 0,1277 & & & & \\
\hline White males & 0,41 & 0,2947 & 0,3740 & 0,3927 & & & & & \\
\hline White females & 0,24 & 0,1441 & 0,1968 & & 0,2129 & & & & \\
\hline
\end{tabular}

Note: Only the first three variables entered are recorded above. The total $\mathbf{R}^{2}$ represents the first five variables entered in all cases. The values in the rows should read from the lowest to highest in order to establish the variable's order of entry. 
Table 2 Percent labour market discrimination explained by all levels of education for race/sex groups

\begin{tabular}{|c|c|c|c|c|}
\hline Race/Sex & $\begin{array}{c}\text { Occupational } \\
\text { level } \\
\text { variance } \\
1\end{array}$ & $\begin{array}{c}\text { Years of } \\
\text { schooling } \\
\text { variance } \\
2\end{array}$ & $\begin{array}{c}\text { Predicted } \\
\text { occupational } \\
\text { level variance } \\
3\end{array}$ & $\begin{array}{l}\text { Variance percent } \\
\text { explained by } \\
\text { education }(3 \div 1)^{d} \\
4\end{array}$ \\
\hline White males & $(44,44)$ & $(10,69$ years $)$ & $(3,65920)$ & - \\
\hline White females & 0,40 & 0,15 & 0,55 & $100,00 c$ \\
\hline Coloured males & 18,96 & 3,37 & 12,33 & 65,03 \\
\hline Coloured females & 17,52 & 3,43 & 12,55 & 71,63 \\
\hline Asian males & 15,22 & 3,11 & 11,38 & 74,77 \\
\hline Asian females & 16,71 & 4,62 & 16,91 & $100,00 \mathrm{c}$ \\
\hline Black males & 25,11 & 4,82 & 17,64 & 70,25 \\
\hline Black females & 25,77 & 2,25 & 8,23 & 31,94 \\
\hline
\end{tabular}

Notes:

a Figures in column 2 are the year differences in average years of schooling from White males.

b The values in column 3 are calculated by multiplying the absolute schooling values in column 2 with the White male's educational coefficient, i.e. 3,65920 .

c In these two cases education explains all of the occupational level differences which exist between White and Asian females and White males.

d Column 4 is a constructed statistic which attempts to estimate the importance and role of education in explaining occupational level differences between race/sex groups. This derived statistic is based on Masters'14 conceptual framework which incorporates a modified version of Duncan's approach and some of Michelson's ideas. In our case, separate occupational level functions were estimated for the different race/sex groups. It was assumed in the calculations of the values in column 3 that the White male's occupational level function is specified a perfect fit (i.e. given a set of values for the independent variables, one can then predict the individual's occupational level with 'perfect accuracy'). For example, the occupational level difference between White males $(44,44)$ and Coloured males $(25,48)$ is 18,96 . The extent to which education explains this difference is given in Table 2 column 4. The variance in education between White and Coloured males is 3,37 years (Table 2, column 2). After multiplying it with the White male's coefficient $(3,65920)$, Coloured males obtain a 12,33 value. This value represents a two-thirds or $65,03 \%$ explanation of the difference existing between the absolute and predicted occupational levels of White and Coloured males, which can be ascribed to educational differences.

Of the existing differences in occupational level, how much can now be attributed to education? From Table 2 it is apparent that more education for all groups, except Whites and Asian females, is essential and required if they are to uplift themselves from unemployment, underutilization or low wage and occupational levels. In almost all cases, two thirds to three quarters of the difference between the groups' occupational levels is explained by education.

\section{Conclusion}

It is clear that in the case of the individual, the achievement of more years of schooling is imperative if the person aspires to improve his earnings and quality of life. To the employer it should be clear that for employees to enjoy equal employment opportunities the organization's personnel policies and employment practices need review to ensure fair standards of evaluation and advancement for all. If South Africa wants to increase its economic growth and provide sufficient employment for all its people, the data clearly points out the need to impose some minimum level of compulsory education to the non-White groups. Basic education in reading, writing and arithmetic is the foundation to the individual's employability, and since employability is employment's prerequisite and employment the source of that income, ${ }^{13}$ his preparation to enter the labour market successfully is almost totally dependent on educational level.

In summary, this study highlighted the occupational determinants most critical in the process of gaining employment status for the race/sex groups. It was statistically proven that education explains up to $75 \%$ of the occupational level differences among groups, and this establishes the significance of compulsory schooling for all in South Africa. The results do not, however, deny that labour market discrimination looms large among the explanations for education deficiencies among the various race groups, but it does suggest that alleviation of discrimination alone will not bring about rapid redress in the occupational structure and employment of nonWhites in South Africa.

Unless equal employment opportunities and specific job upgrading programs are of fered to all employees, any new efforts directed at the non-White groups will be wasted, because without more human capital investment in the non-White group they will not be able to survive in the primary labour market jobs once they arrive there. Only then will South African employers have a foundation for an effective and non-discriminatory human resources development policy.

\section{References}

1. BURACK, E.H. \& GUTHERIDGE, T.G. 'Institutional Manpower Planning: Rhetoric Versus Reality'. Calif. Manage. Rev., 1978, 20(3), p. 13.

2. SCHULTZ, T.W. 'Capital Formation by Education'. J. Political Economy, 1960, 68(6), p.571.

3. DOERINGER, P.B. \& PIORE, M.J. Internal Labor Markets and Manpower Analysis. Lexington, Massachusetts: D.C. Heath, 1971.

4. HARBISON, F.H. Human Resources as the Wealth of Nations. New York: Oxford University Press, 1973, p.14.

5. VAN DER MERWE, P.J. 'Black Employment Problems in South Africa'. Finance and Trade Review, 1976, $12(2)$, p.46. 
6. MARSHALL, R. \& PERLMAN, R. An Anthology of Labor Economics: Readings and Commentary. New York: Wiley, 1972, p.865.

7. BLAU, P.M. \& DUNCAN, O.D. The American Occupational Structure. New York: Wiley, 1967, pp.404-405.

8. BERG, I. Education and Jobs. New York: Praeger, 1970.

9. PARNES, H.S. \& KOHEN, A.I. 'Occupational Information and Labor Market Status: The Case of Young Men'. J. Hum. Resources, 1975, 10(1), p.44.

10. ADAMS, A.V. 'Black-White Occupational Differentials in Southern Metropolitan Employment'. J. Hum. Resources, 1972. 8(4), p.500.
11. LEIGH, D.E. An Analysis of the Determinants of Occupational Upgrading. Madison, Wisconsin: Institute for Research on Poverty, University of Wisconsin, 1975.

12. LOMBARD, B.U. 'A Critical Analysis of the Occupational Structure Determinants by Race and Labor Policy Implications in the Republic of South Africa'. Unpublished Ph.D. dissertation. College of Business, University of Utah, 1979, pp.353-360.

13. MANGUM, G.L. Employability, Employment and Income. Salt Lake City, Utah, Olympus, 1976.

14. MASTERS, S.H. Black-White Income Differentials: Empirical Studies and Policy Implications. New York: Academic Press, 1975, p. 104. 